DOI https://doi.org/10.30525/978-9934-26-111-4-65

\title{
ПЕРСПЕКТИВИ ВИКОРИСТАННЯ ВИДІВ ІНТРОДУЦЕНТІВ У ЛІСОВИХ НАСАДЖЕННЯХ ЛІВОБЕРЕЖНОГО ЛІСОСТЕПУ УКРАЇНИ
}

\author{
Познякова C. I. \\ кандидат сільськогосподарських наук, \\ доиент кафедри лісівництва імені Б. Ф. Остапенка \\ Харківський національний аграрний університет імені В. В. Докучаєва
}

\section{Швиденко І. М.}

кандидат сільськогосподарських наук, дочент кафедри садово-паркового господарства

Харківський національний аграрний університет імені В. В. Докучаєва м. Харків, Україна

Широке впровадження у виробничу практику нових перспективних видів і форм рослин, відібраних у результаті багаторічних інтродукційних досліджень, залишається одним 3 актуальних завдань інтродукції. Види інтродуценти широко використовують у лісовому i садово-парковому господарствах, захисному і плантаційному лісорозведенні. Оптимальне застосування перспективних інтродуцентів при лісовідновленні та лісорозведенні забезпечує високу адаптаційну здатність лісів до мінливих екологічних умов і гарантує належне виконання лісовими екосистемами екологічних, соціальних, економічних функцій. Введення нових видів у лісові насадження може сприяти підвищенню продуктивності деревостанів, скороченню термінів їх вирощування, посиленню захисної властивості насаджень, стійкості до несприятливих факторів середовища [1].

Введення нових видів повинно базуватись на чіткому розумінні тих переваг, які лісівник отримає від їх впровадження. Тільки в таких випадках виправдано введення нових порід. Хоча перспективність багатьох деревних і чагарникових видів вже відома, лісове господарство має обмежені можливості впровадження інтродукованих видів у лісокультурне виробництво внаслідок відсутності достатньої лісонасінної бази та незначної кількості науково-виробничих об'єктів, де проводяться дослідження 3 питань акліматизації того чи іншого виду [1]. 
Значний інтерес викликають види деревних рослин 3 Північної Америки, більшість 3 яких мають високу продуктивність, стійкість, здатність зберігати відмінні декоративні якості. Ці види широко використовують для створення штучних насаджень різного цільового призначення: лісових культур, захисних та озеленювальних насаджень.

Для вивчення видового різноманіття порід інтродуцентів, які ростуть у лісових насадженнях Лівобережного Лісостепу України, ми проаналізували бази даних лісогосподарських підприємств. У штучних насадженнях Лівобережного Лісостепу широко культивують модрину європейську (Larix decidua Mill.), модрину японську (Larix leptolepis Govd.), ялину європейську (Picea abies (L.) Karst.), сосну Веймутова (Pinus strobus L.), сосну жовту (Pinus ponderosa Dougl. ex Laws.), сосну Банкса (Pinus banksiana Lamb.), сосну кримську (Pinus pallasiana D. Don), псевдотсугу Мензіса (Pseudotsuga menziesii (Mirb) Franco), дуб червоний (Quercus rubra L.), горіх грецький (Juglans regia L.), горіх чорний (Juglans nigra L.), бархат амурський (Phellodendron amurense Rupr.). Ці види інтродуценти в умовах Лівобережного Лісостепу відрізняються високою інтенсивністю росту та можуть формувати високопродуктивні деревостани $[2,3,4,5]$.

Як свідчать наші дані, Quercus rubra L. має найбільше впровадження у лісові культури Лівобережної України, майже у всіх лісгоспах він входить до складу насаджень. У 70-х роках минулого століття площа лісових культур 3 перевагою у складі Quercus rubra L. у лісовому фонді України перевищувала понад 6 тис. га [6]. Але цей вид, що має достатньо цінну деревину і $є$ швидкорослим, занесений до списку інвазійних видів, які є найбільш небезпечними для місцевої флори [7]. Результати наших досліджень показують, що дуб червоний має кращі таксаційні показники, більші прирости, кращий санітарний стан і в лісових насадженнях може пригнічувати дуб звичайний. На багатих зволожених грунтах, в умовах свіжого та вологого груду, цей вид інтродуцент витісняє аборигенний вид - дуб звичайний. Саме в багатих лісорослинних умовах Quercus rubra L. слід обмежувати у складі деревостану. Проте, найбільша площа лісових культур із дубом червоним створена на бідніших грунтах в умовах $\mathrm{B}_{2}$-дС. Quercus rubra L., будучи швидкорослою і більш конкурентоспроможною породою, ніж дуб звичайний, може бути успішно використаний як компонент соснових насаджень у суборових умовах. Крім того, дуб червоний більш вологолюбний, ніж дуб звичайний, тому вологість клімату, грунту є лімітуючим фактором його поширення у посушливих умовах. За умови ефективного ведення лісового господарства, з урахуванням 
принципів лісової типології, Quercus rubra L. не є небезпечним видом для місцевої флори, хоча і має ознаки інвазійного виду [8].

Вчені, лісівники зазначають, що повинна бути не тотальна заборона впровадження швидкоростучих і можливо навіть надто конкурентних деревних видів у наші ліси, а правильне культивування, ретельний контроль за ними i розумне регулювання їх чисельності у складі насаджень, різноманітними лісогосподарськими заходами, в першу чергу доглядовими рубаннями, що запобігатиме розвитку їх інвазивності [8].

Модрина європейська у лісгоспах Лівобережного Лісостепу України формує як чисті, так і мішані насадження, на відносно невеликій площі. Введення Larix decidua Mill. у лісові культури можна рекомендувати 3 метою підвищення загальної продуктивності насаджень та збільшення біологічного різноманіття. У лісах, що використовують як місця відпочинку, модрина європейська підвищує естетичні властивості насаджень.

На особливу увагу заслуговує горіх чорний. Він є перспективним видом інтродуцентом, який в умовах Правобережного Лісостепу займає вже тисячі гектарів лісових площ. Історія розведення Juglans nigra L. у нашій країні нараховує більше двохсот років. Найкращі результати за продуктивністю цей вид показує у лісостеповій зоні, але його можна інтродукувати і у північно-степові райони.

Бархат амурський також $є$ цінним видом інтродуцентом. У ДП «Жовтневе ЛГ» (Харківська область) майже 137 га насаджень, до складу яких входить цей вид. Він має високоякісну деревину та цінні лікарські властивості.

Крім того, слід звернути увагу на дослідження 3 інтродукції в дендрологічних парках, які залишаються найбільшими науковими центрами щодо вивчення інтродукції, акліматизації деревних рослин. Дендрологічний парк Харківського національного аграрного університету ім. В.В. Докучаєва $\epsilon$ саме таким центром в умовах Лівобережного Лісостепу України [9].

Серед хвойних, які ростуть у дендропарку, найперспективнішою $\epsilon$ Pseudotsuga menziesii (Mirb.) Franco., вид що формує темнохвойні високопродуктивні гірські ліси в Північній Америці. У дендропарку ХНАУ дерева Pseudotsuga menziesii (Mirb.) Franco. Відрізняються найбільшим діаметром - близько $50 \mathrm{~cm} \mathrm{і} \mathrm{висотою} \mathrm{21-22} \mathrm{м}$ у віці 52 роки. Індекс санітарного стану - I,0, всі дерева здорові без ознак ослаблення, не мають зовнішніх ознак пошкодження, формують густу декоративну крону. Щороку спостерігаємо рясне плодоношення, 
$\epsilon$ самосів. Ураховуючи показники росту, стану та продуктивності, псевдотсуга Мензіса $\epsilon$ перспективним інтродуцентом у лісових насадженнях Лівобережного Лісостепу України $[2,3]$.

Серед різноманіття інтродукованих видів, види роду Pinus L. є дуже перспективними 3 огляду на притаманні їм екологічні властивості, а саме: посухостійкість, морозостійкість, невимогливість до трофності грунтів. Інтродукція видів роду Pinus L. зосереджена переважно в ботанічних садах i дендропарках. Лише небагато видів ростуть на лісокультурних площах у різних лісгоспах країни. У дендропарку ХНАУ представлена чисельна колекція видів роду Pinus L. Перспективними інтродуцентами для Лівобережного Лісостепу є сосна жовта, сосна Веймутова, сосна чорна, сосна гімалайська.

У лісових насадженнях і в дендрологічних парках необхідно і надалі проводити моніторинг особливостей росту, розмноження, поширення видів інтродуцентів, інвазійних видів деревних рослин і своєчасно та ефективно здійснювати доглядові роботи.

\section{Література:}

1. Яцик Р.М., Гайда Ю.І., Гудима В.М. Основи інтродукції та адаптації деревно-кущових видів рослин. Івано-Франківськ: HАIP, 2017. $175 \mathrm{c}$.

2. Плотнікова О.М. Комплексне оцінювання перспективності псевдотсуги Мензіса (Pseudotsuga Menziesii (Mirb.) Franco) в умовах Лісостепу України. Лісівництво $i$ агролісомеліорація. 2018. Вип. 132. С. 73-83.

3. Познякова С.I., Лось С.А. Дендрологія. Голонасінні: навч. посібник. Харків: Харк. нац. аграр. ун-т ім. В.В. Докучаєва, 2015. 199 с.

4. Познякова С.I. Породи інтродуценти в лісових насадженнях ДП »Гадяцьке ЛГ». Вісник ХНАУ. 2019. № 2. С. 142-148.

5. Познякова С.I. Особливості формування лісових насаджень в різних типах лісу в ДП «Краснопільський агролісгосп» Вісник ХНАУ. 2020. № 1. C. 183-191.

6. Івченко А.І. Історія впровадження дуба червоного. Науковий вісник УкрДЛТУ. 2002. Вип. 12.4. С 35-40.

7. Зав'ялова Л.В. Види інвазійних рослин, небезпечні для природного фіторізноманіття об'єктів природно-заповідного фонду України. Біологічні системи. 2017. Т. 9. Вип. 1. С. 87-107.

8. Познякова С.I. Сучасний стан видів інтродуцентів в лісових насадженнях i дендропарках Лівобережного Лісостепу України. Збереження рослин у зв'язку зі змінами клімату та біологічними 
інвазіями: матеріали міжнародної наукової конференції (Біла Церква, 31 березня 2021 року ) Біла Церква: ТОВ «Білоцерківдрук», 2021. С. $115-120$.

9. Ситнік І.Й. Парки Харківського національного аграрного університету ім. В.В. Докучаєва. Харк. нац. аграр. ун-т ім. В.В. Докучаєва, 2017. 225 с. 